\title{
Antibacterial activity of leaf extract of Chromolaena odorata and the effect of its combination with some conventional antibiotics on Pseudomonas aeruginosa isolated from wounds
}

\author{
P. Odinakachukwu Omeke, J. Okechukwu Obi, N. A. Ibuchukwu Orabueze ${ }^{1,2}$, Anthony Chibuogwu Ike ${ }^{1,3 *}$ \\ ${ }^{1}$ Department of Microbiology, University of Nigeria, Nsukka, Nigeria, ${ }^{2}$ Department of Medical Microbiology, College of Medicine, University of Nigeria Enugu \\ Campus, Enugu, Nigeria, ${ }^{3}$ Department of Biological Sciences, Benue State University, Makurdi, Nigeria
}

\section{ARTICLE INFO}

Article history:

Received on: July 27, 2017

Accepted on: September 23, 2018

Available online: April 05, 2019

\section{Key words:}

Antibacterial activity,

Chromolaena odorata,

Crude extracts,

Herb-drug combination,

Pseudomonas aeruginosa,

Standard antibiotics

\section{ABSTRACT}

This study was carried out to investigate the in vitro antimicrobial properties of crude methanolic extract of Chromolaena odorata and its interactions with some standard antibiotics (ofloxacin, ciprofloxacin, and gentamicin) on Pseudomonas aeruginosa isolated from wound samples. P. aeruginosa was isolated from wound samples from hospital patients in Enugu State, Nigeria, using standard bacteriological methods. Methanolic extraction of C. odorata was carried out using Soxhlet extractor. The antimicrobial activity and in vitro interactions were evaluated using a combination of agar well diffusion and broth dilution techniques. The findings of this study showed that all the $P$. aeruginosa isolates were susceptible to the $C$. odorata methanolic crude extract at high concentrations. There was an enhancement of the potency of the methanolic crude extract when combined with low concentrations of standard antibiotics compared to its potency when tested alone. Our findings give credence to the folkloric use of C. odorata for the treatment of wounds, especially P. aeruginosa-infected wounds. There could be beneficial clinical application of the coadministration of standard antibiotics and the crude extract of $C$. odorata in the treatment of wound infections caused by P. aeruginosa.

\section{INTRODUCTION}

A wound is a disruption of normal anatomic structure and function of the skin causing breakdown of the protective function of the skin [1]. It constitutes a major cause of physical disability [2]. Wounds provide moist, warm, and nutritious environments which are conducive for microbial colonization and proliferation causing infections which delay wound healing. This can, in turn, cause wound breakdown leading to increased hospital stay, morbidity, and in some cases, even mortality. Infection of wound is the successful invasion and proliferation by one or more species of microorganisms anywhere within the body's sterile tissues, sometimes resulting in pus formation, and Pseudomonas aeruginosa is one of the species of microorganisms implicated in wound infection [3].

Many traditional medicinal herbs and plant parts (leaves, stem, roots, and bark) have been reported to be effective in providing health-

\footnotetext{
*Corresponding Author:

Anthony Chibuogwu Ike,

Department of Microbiology,

University of Nigeria, Nsukka, Nigeria;

Department of Biological Sciences,

Benue State University, Makurdi, Nigeria.

Email: anthonyc.ike@unn.edu.ng
}

care services to rural dwellers and in the treatment of wounds and combating serious diseases in the world at large [4-6]. Plants contain pharmacologically important phytochemicals such as alkaloids, essential oils, flavonoids, tannins, terpenoids, saponins, and phenolic compounds with essential antimicrobial activities. Chromolaena odorata is one of the plants implicated in wound healing. C. odorata is a fast growing, abundant, and widespread perennial scandent or semiwoody flowering shrub in the sunflower family of Asteraceae [7-10]. This plant is known to have originated from Central and South America but is now distributed throughout Africa and Tropical Asia. C. odorata occupies different types of lands where it forms dense strands that prevent the establishment of other flora as it possesses allelopathic potentials and growth inhibitors [11].

The plant is traditionally used in disinfecting wounds, preventing blood loss from wounds, and treating of open wounds [9]. It is used by traditional medicine practitioners for the treatment of burns, wound healing, skin infections, postnatal wounds, leech bite, soft tissue wounds, and liver diseases [12-17]. The common names of C. odorata include Awolowo weed, Siam weed, Elizabeth weed, Enugu plantation weed $[9,18]$, bitter bush, airplane plant [19], jack in the bush [15], Christmas bush, common floss flower [20], and independence leaf among others.

Many commonly used antibiotics have become less effective against certain pathogens, thereby threatening man's ability to treat wound 
infections. The emergence of multidrug-resistant (MDR) pathogens and the increasing concerns on high rate of organisms resistance to antibiotics and synthetic drugs used in the treatment of wounds, and the tremendous impact on the cost of health-care delivery systems across the globe has led to the search for alternative wound healing agents $[21,22]$. This search has, in turn, led to the recognition of the potentials of medicinal plant extracts for treating the infections associated to these pathogens [23].

Synergism between plant extracts and commonly used antibiotics has been reported and recently has become part of a multitargeted approach used against multidrugs-resistant bacteria [23].

The present study aims to assess the antimicrobial potency of C. odorata leaf crude extract, alone and in combination with antibiotics, on MDR $P$. aeruginosa isolated from wounds from hospital patients in Enugu State, Nigeria.

\section{MATERIALS AND METHODS}

\subsection{Plant Materials and Extraction}

Fresh leaf samples of $C$. odorata were harvested from Gardens in Obukpa, Enugu State, Nigeria, and were authenticated by a plant taxonomist in the Department of Plant Science and Biotechnology, University of Nigeria, Nsukka. The leaves were air-dried at room temperature and pulverized to obtain a fine powder. About $500 \mathrm{~g}$ of pulverized material was extracted with $1.5 \mathrm{~L}$ of methanol using Soxhlet extractor (Buchi, Japan). The extracts were filtered using Whatman no. 1 filter paper and then dried in a rotary evaporator (Merck, Germany) for $5-6 \mathrm{~h}$ at $60^{\circ} \mathrm{C}$. The extract obtained was weighed and stored in sterile airtight bottles in the refrigerator until used. The required concentrations of $400 \mathrm{mg} / \mathrm{mL}, 200 \mathrm{mg} / \mathrm{mL}, 100 \mathrm{mg} / \mathrm{mL}$, $50 \mathrm{mg} / \mathrm{mL}, 25 \mathrm{mg} / \mathrm{mL}$, and $12.5 \mathrm{mg} / \mathrm{mL}$ were prepared by dissolving $400 \mathrm{mg}$ of the methanolic extract in $1 \mathrm{~mL}$ of $20 \%$ dimethyl sulfoxide (DMSO) with subsequent two-fold serial dilutions with 20\% DMSO.

\subsection{Test Microorganism}

The test organisms used for these experiments were isolated from wound infections from hospital patients in Enugu State, Nigeria. Identification of the bacterial isolates was performed according to standard bacteriological techniques. A 24-h-old axenic culture of the $P$. aeruginosa was harvested and standardized to a microbial population of $1.5 \times 10^{8} \mathrm{cfu} / \mathrm{mL}$ by comparing with McFarland 0.5 standard.

\subsection{Plant Extract Sensitivity Testing}

The antibacterial activity of $C$. odorata extracts was checked by agar well diffusion method. The standardized inoculum of $P$. aeruginosa $\left(1.5 \times 10^{8} \mathrm{cfu} / \mathrm{mL}\right)$ was streaked evenly on the surface of MuellerHinton agar (Lab M, Lancashire, United Kingdom) with the aid of sterile swab stick. A sterile cork borer of $6 \mathrm{~mm}$ in diameter was used to aseptically puncture holes in the seeded agar plates. After which, $0.2 \mathrm{~mL}$ of each of the six different concentrations of the plant extract were introduced into the respective wells and allowed to diffuse into the medium for $1 \mathrm{~h}$ before incubation at $37^{\circ} \mathrm{C}$ for $24 \mathrm{~h}$. After $24 \mathrm{~h}$, zones of inhibition were measured. The $20 \%$ DMSO served as control. The plates were prepared in triplicates for each isolate and reported as mean.

A parallel analysis with conventional antibiotic discs (ceftazidime $30 \mu \mathrm{g}$, cefuroxime $30 \mu \mathrm{g}$, ampicillin $10 \mu \mathrm{g}$, clavulanate amoxicillin [AUG] $30 \mu \mathrm{g}$, nitrofurantoin $30 \mu \mathrm{g}$, ciprofloxacin $5 \mu \mathrm{g}$, gentamicin
$10 \mu \mathrm{g}$, and ofloxacin $5 \mu \mathrm{g}$ ) was conducted to determine the possible MDR nature of the isolates and to compare the potency of the crude methanol extract to the conventional antibiotics. The susceptibility pattern was compared using standard antibiogram chart [24].

\subsection{Determination of Minimum Inhibition Concentration (MIC) and Minimum Bactericidal Concentration (MBC) of Standard Antibiotics on the $\boldsymbol{P}$. aeruginosa Isolates}

The following antibiotic powders (ofloxacin, ciprofloxacin, and gentamicin) were dissolved in appropriate diluents to obtain a stock solution of $5120 \mu \mathrm{g} / \mathrm{mL}$ each. Subsequent antibiotic dilutions were made in sterile Mueller-Hinton broth, and an equal volume of the standardized inoculums was added to equal volume of antibiotic concentration. Antibiotic concentration ranges were prepared one step higher than the final dilutions range required to accommodate the addition of an equal volume of inoculum [25]. The MIC was taken as the lowest concentration of antibiotic at which there was no visible growth of the organism after $24 \mathrm{~h}$ incubation. The MBC assay was carried out by plating out the tubes that showed no sign of growth on antibiotic-free Mueller-Hinton agar plates. The MBC was taken as the lowest concentration of antibiotic that totally prevented the growth of the $P$. aeruginosa (100\% killing), after subculture on antibiotic-free Mueller-Hinton agar plates.

\subsection{Evaluation of the Interaction between the Methanol Crude Extract and Ineffective Concentrations of the Standard Antibiotics}

The different concentrations $(400 \mathrm{mg} / \mathrm{mL}, 200 \mathrm{mg} / \mathrm{mL}, 100 \mathrm{mg} / \mathrm{mL}$, $50 \mathrm{mg} / \mathrm{mL}, 25 \mathrm{mg} / \mathrm{mL}$, and $12.5 \mathrm{mg} / \mathrm{mL}$ ) of the plant crude methanol extract were, respectively, combined with the antibiotics (ofloxacin, ciprofloxacin, and gentamicin) to check for interactions. In brief, $1 \mathrm{~mL}$ of the different concentrations of the plant crude methanol extract was, respectively, mixed with $1 \mathrm{~mL}$ of ineffective antibiotic concentration (concentration below the MIC). The standardized inoculums of $P$. aeruginosa $1.5 \times 10^{8} \mathrm{cfu} / \mathrm{mL}$ were streaked evenly on the surface of Mueller-Hinton agar (Lab M, Lancashire, United Kingdom) with the aid of sterile swab stick. A sterile cork borer of $6 \mathrm{~mm}$ in diameter was used to aseptically puncture holes in the seeded agar plates, and about $0.2 \mathrm{~mL}$ of each of the six different concentrations of the herb-drug combination were introduced into the respective wells and allowed to diffuse into the medium for $1 \mathrm{~h}$ before incubation for $24 \mathrm{~h}$ at $37^{\circ} \mathrm{C}$. After $24 \mathrm{~h}$, zones of inhibition were measured. The plates were prepared in triplicates for each isolate. The MIC of the extract-drug combination taken as the lowest concentration of the extract-drug combinations at which there was no visible growth of the $P$. aeruginosa test isolates after $24 \mathrm{~h}$ incubation was determined as previously described [25]. The $\mathrm{MBC}$ taken as the lowest concentration of extract-drug combination that totally prevented the growth of the $P$. aeruginosa after subculture on antibiotic-free Mueller-Hinton agar plates was determined.

\subsection{Herb-drug Combination Stability Check}

The stability of the combined therapy (herb-drug combinations) was done to check if the potency of the different combination increased or decreased with time. The herb-drug mixtures kept at room temperature were tested on the $P$. aeruginosa isolates within time intervals of $24 \mathrm{~h}$ at $24 \mathrm{~h}, 48 \mathrm{~h}$, and $72 \mathrm{~h}$.

\section{RESULTS}

The $P$. aeruginosa wound isolates were all susceptible to the methanolic plant extract at the highest concentration of $400 \mathrm{mg} / \mathrm{mL}$ followed by 
$200 \mathrm{mg} / \mathrm{mL}$. Isolate WS25 was susceptible to all the methanolic extract concentrations, whereas isolates WS34 and WS42 were susceptible only at the highest concentration. The zones of inhibition observed ranged from $8 \mathrm{~mm}$ to $15 \mathrm{~mm}$ [Table 1]. All the isolates were classified as MDR, being resistant to a minimum of 5 of the 8 antibiotics tested [Table 2].

Table 3 shows the minimal inhibitory concentrations and minimal bactericidal concentrations of the standard antibiotics on the $P$. aeruginosa wound isolates. The MIC values for ofloxacin, ciprofloxacin, and gentamicin range from 0.5 to $16.0 \mu \mathrm{g} / \mathrm{mL}, 1.0$ to $16.0 \mu \mathrm{g} / \mathrm{mL}$, and 2.0 to $32.0 \mu \mathrm{g} / \mathrm{mL}$, respectively. The MBC values for ofloxacin, ciprofloxacin, and gentamicin range from 1.0 to $128.0 \mu \mathrm{g} / \mathrm{mL}, 1.0$ to $64.0 \mu \mathrm{g} / \mathrm{mL}$, and 4.0 to $128 \mu \mathrm{g} / \mathrm{mL}$, respectively. All three drugs were not bactericidal on the isolate WS42. Ciprofloxacin was not bactericidal on the isolate WS35 at the highest concentration analyzed. Gentamicin was not bactericidal on the isolates WS24 and WS37 at the highest concentration analyzed.

Appreciable enhancement of activity was observed with all the combinations in all the concentrations analyzed for all the P. aeruginosa isolates [Figure 1]. The plant extract combinations with ofloxacin had more effect on all the $P$. aeruginosa isolate compared to the other respective combinations with ciprofloxacin and gentamicin, except for isolate WS45 where the plant extract-gentamicin combination showed the highest effect [Figure 1]. The plant extract-ofloxacin combination was followed by plant extract-ciprofloxacin combination in isolates WS 24, WS25, WS37, and WS42, while in isolates WS27 and WS34, it was followed by the plant extract-gentamicin combination. The differences between the plant extract-ciprofloxacin and plant extract-

Table 1: Antibacterial activity of the methanolic extract on the Pseudomonas aeruginosa wound isolates (mean values of zones of inhibition)

\begin{tabular}{lcccccc} 
Isolates code & \multicolumn{7}{c}{ Concentrations $(\mathbf{m g} / \mathbf{m L})(\mathbf{m m})$} \\
\cline { 2 - 7 } no & $\mathbf{4 0 0}$ & $\mathbf{2 0 0}$ & $\mathbf{1 0 0}$ & $\mathbf{5 0}$ & $\mathbf{2 5}$ & $\mathbf{1 2 . 5}$ \\
WS17 & 11 & 9 & 0 & 0 & 0 & 0 \\
WS24 & 12 & 10.5 & 0 & 0 & 0 & 0 \\
WS25 & 15 & 13 & 11.5 & 10 & 8 & 8 \\
WS27 & 11 & 10 & 8 & 0 & 0 & 0 \\
WS34 & 10 & 0 & 0 & 0 & 0 & 0 \\
WS35 & 12.5 & 10 & 0 & 0 & 0 & 0 \\
WS42 & 9 & 0 & 0 & 0 & 0 & 0 \\
WS45 & 14 & 11.5 & 8.5 & 0 & 0 & 0 \\
\hline
\end{tabular}

Table 2: Antibiotic susceptibility pattern of Pseudomonas aeruginosa isolates to the standard antibiotics

\begin{tabular}{lllllllll} 
Isolates & CAZ & CRX & GEN & AMP & CPR & OFL & AUG & NIT \\
WS17 & R & R & S & R & S & I & R & R \\
WS24 & R & R & R & R & R & R & R & R \\
WS25 & R & R & S & R & S & S & R & R \\
WS27 & R & R & S & R & S & S & R & R \\
WS34 & R & R & S & R & S & I & R & R \\
WS35 & R & R & S & R & S & R & R & R \\
WS37 & R & R & R & R & R & R & R & R \\
WS42 & R & R & R & R & R & R & R & R \\
WS45 & R & R & R & R & S & R & R & S \\
\hline
\end{tabular}

S: Susceptible, I: Intermediate, R: Resistance, CAZ: Ceftazidime, CRX: Cefuroxime, AM:= Ampicillin, AUG: Clavulanate amoxicillin, NIT: Nitrofurantoin,

CPR: Ciprofloxacin, GEN=Gentamicin, OFL: Ofloxacin gentamicin combinations in isolates WS34 and WS37 were only marginal [Figure 1].

The MIC values for the methanolic plant extract and the herb-drug combination range from $12.5 \mathrm{mg} / \mathrm{mL}$ to $400 \mathrm{mg} / \mathrm{mL}$ and $12.5 \mathrm{mg} / \mathrm{mL}$ to $200 \mathrm{mg} / \mathrm{mL}$, respectively [Table 4]. The methanolic plant extract has MIC value of $400 \mathrm{mg} / \mathrm{ml}$ on the isolates WS34 and WS42. In general, a remarkable increase in bioactivity was recorded against all the isolates as lower MIC values were recorded for the herb-drug combinations, respectively. No difference in potency was observed for isolate WS25 where MIC values for all the combination and crude extract remained at $12.5 \mathrm{mg} / \mathrm{mL}$.

The MBC values for the methanolic plant extract and the herb-drug combinations range from $200 \mathrm{mg} / \mathrm{mL}$ to $400 \mathrm{mg} / \mathrm{mL}$ and $12.5 \mathrm{mg} / \mathrm{mL}$ to $200 \mathrm{mg} / \mathrm{mL}$, respectively [Table 4]. Nevertheless, the methanolic plant extract was not bactericidal on isolates WS24 and WS42 at the tested concentrations.

There was no alteration in the potency of the herb-drug combinations with respect to time variation [Table 5].

\section{DISCUSSION}

The clinical success of medicinal extracts from plants has rekindled the interest in medicinal plants for the treatment of diseases and as potential sources of novel drugs. Herbal medicine has been widely used and forms an integral part of primary health care in many places

Table 3: MIC/MBC of the standard antibiotics on the isolates

\begin{tabular}{lccc} 
Isolates code no & OFL $(\mu \mathrm{g} / \mathrm{mL})$ & CIP $(\mu \mathrm{g} / \mathbf{m L})$ & GEN $(\mu \mathrm{g} / \mathrm{mL})$ \\
WS17 & $4 / 32$ & $2 / 32$ & $4 / 64$ \\
WS24 & $8 / 64$ & $8 / 32$ & $16 / *$ \\
WS25 & $0.5 / 1$ & $1 / 1$ & $2 / 4$ \\
WS27 & $1 / 1$ & $2 / 2$ & $8 / 128$ \\
WS34 & $4 / 64$ & $2 / 32$ & $2 / 64$ \\
WS35 & $8 / 128$ & $4 / *$ & $8 / 128$ \\
WS37 & $8 / 64$ & $8 / 64$ & $16 / *$ \\
WS42 & $16 / *$ & $16 / *$ & $32 / *$ \\
WS45 & $8 / 128$ & $4 / 64$ & $16 / 128$ \\
\hline
\end{tabular}

*Not bactericidal. MIC: Minimum inhibitory concentration, MBC: Minimum bactericidal concentration

Table 4: MIC/MBC values of the methanolic plant extract and the herb-drug combination on the test isolates

\begin{tabular}{lcccc}
$\begin{array}{l}\text { Test isolate } \\
\text { code number }\end{array}$ & \multicolumn{4}{c}{$\begin{array}{c}\text { Methanolic extract and herb-drug combinations } \\
\text { MIC/MBC (mg/ml) }\end{array}$} \\
& $\begin{array}{c}\text { Plant extract } \\
\text { MeOFl }\end{array}$ & MeCIP & MeGEN \\
WS17 & $200 / 400$ & $50 / 100$ & $100 / 200$ & $50 / 400$ \\
WS24 & $200 / *$ & $25 / 400$ & $50 / 400$ & $200 / 200$ \\
WS25 & $12.5 / 200$ & $12.5 / 12.5$ & $12.5 / 200$ & $12.5 / 100$ \\
WS27 & $100 / 200$ & $25 / 200$ & $50 / 200$ & $25 / 100$ \\
WS34 & $400 / 400$ & $25 / 200$ & $200 / 400$ & $200 / 400$ \\
WS37 & $100 / 200$ & $25 / 100$ & $25 / 200$ & $12.5 / 200$ \\
WS42 & $400 / *$ & $50 / 200$ & $200 / 200$ & $200 / 400$ \\
WS45 & $100 / 400$ & $25 / 200$ & $25 / 200$ & $12.5 / 200$ \\
\hline
\end{tabular}

*Not bactericidal; MeGEN methanolic extract and gentamicin; MeCIP: Methanolic extract and ciprofloxacin, MeOFL: Methanolic extract and ofloxacin 
Table 5: Combine therapy stability - MBC with time variation

\begin{tabular}{|c|c|c|c|c|c|c|c|c|c|}
\hline \multirow[t]{2}{*}{ Isolates } & \multicolumn{3}{|c|}{ MeCIP } & \multicolumn{3}{|c|}{ MeOFL } & \multicolumn{3}{|c|}{ MeGEN } \\
\hline & $24 \mathrm{~h}$ & $48 h$ & $72 \mathrm{~h}$ & $24 \mathrm{~h}$ & $48 h$ & $72 \mathrm{~h}$ & $24 \mathrm{~h}$ & $48 \mathrm{~h}$ & $72 \mathrm{~h}$ \\
\hline WS24 & 400 & 400 & 400 & 400 & 400 & 400 & 200 & 200 & 200 \\
\hline WS25 & 200 & 200 & 200 & 12.5 & 12.5 & 12.5 & 100 & 100 & 100 \\
\hline WS37 & 200 & 200 & 200 & 100 & 100 & 100 & 200 & 200 & 200 \\
\hline WS42 & 200 & 200 & 200 & 200 & 200 & 200 & 400 & 400 & 400 \\
\hline WS45 & 200 & 200 & 200 & 200 & 200 & 200 & 200 & 200 & 200 \\
\hline
\end{tabular}

MeGEN: Methanolic extract and gentamicin, MeCIP: Methanolic extract and ciprofloxacin, MeOFL: Methanolic extract and ofloxacin, MBC: Minimum bactericidal concentration

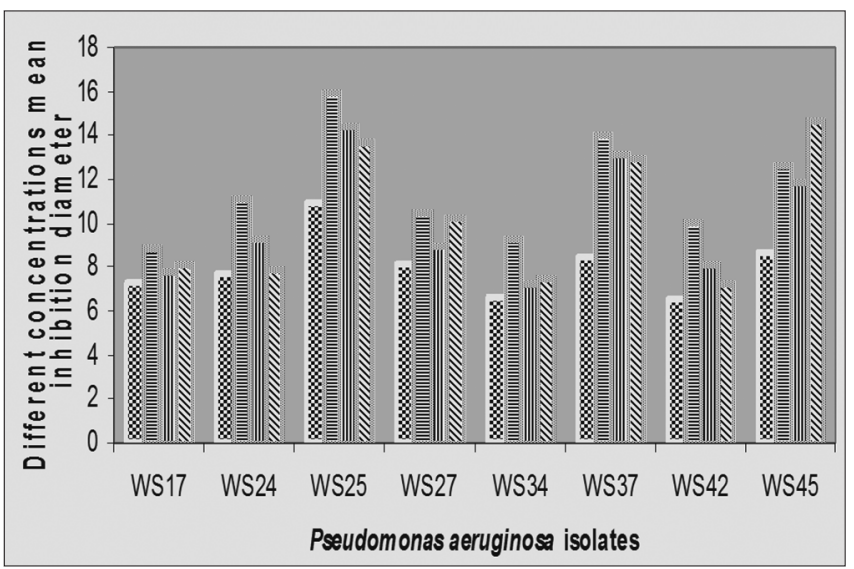

Figure 1: Mean zones of inhibition of the methanolic plant extract and the methanolic plant extract-drug combinations for Pseudomonas aeruginosa isolates. MeGEN: Methanolic extract and gentamicin, MeCIP: Methanolic extract and ciprofloxacin, MeOFL: Methanolic extract and ofloxacin

across the globe, and especially, in rural areas.

This study revealed the antibacterial effect of the leave extracts of $C$. odorata on wound isolates of P. aeruginosa. The extract exhibited antimicrobial effects on the test isolates, showing varying zones of inhibitions. Similar findings have been reported in other studies $[18,20,26]$. The antibacterial properties observed in this study could be attributed to the bioactive compounds present in the plant such as the alkaloids, flavonoids, and essential oils.

The sensitivity of our isolates to the herb and herb-drug combination is low compared to high sensitivity reported in a Gram-positive bacteria (Staphylococcus aureus) to the crude extracts of $C$. odorata in a similar work $[18,20,27]$. This disparity in the pattern of interaction could be as a result of the differences in the cell envelope structure of the test isolates as Gram-positive bacteria do not have an outer membrane and a particular periplasmic space that is present in the Gram-negative bacteria. Furthermore, the observed differences could be attributed to the exposure of our isolates to antibiotics associated with treating wound infections.

There are many documented reports on plant extracts against different bacteria. However, difficulties arise in comparing the results due to different methodologies used including solvents, concentrations, microbial strains, and antimicrobial test methods.

The findings of this study indicate that the methanolic plant extract and herb-drug combinations showed both inhibitory and bactericidal activity against the P. aeruginosa isolates at different high MIC and
MBC values. Our findings agree with the reports of Oko et al. [28] which reported similar high MICs and MBCs of $C$. odorata extract against $P$. aeruginosa. Although the MIC and MBC of the extract were at high concentrations, it can still be harnessed to formulate antibacterial agents for treating some maladies caused by the agents in wounds.

The potency of plant-derived antibacterial agents could be enhanced or depreciated with combination with conventional antibiotics. The different herb-drug combinations presented a remarkable increase in bioactivity compared to the potency observed when the plant extract was tested alone. The best interactions were exhibited by the combination of the methanolic plant extract and fluoroquinolones (ofloxacin and ciprofloxacin). This result indicates that better activities could be achieved when some plant extracts are used in combination with conventional antibiotics, as indicated by the work of Souto de Oliveira et al. [29] who reported synergistic effect of norfloxacin, tetracycline, and erythromycin with ethanol extract of Mangifera indica $\mathrm{L}$. peel against $S$. aureus strains.

In general, our findings on herb-drug combination have shown that the activity of plant antimicrobial agents could be enhanced by combination with conventional antibiotics. They may not have enough antimicrobial activity alone, but when taken in combination with standard drugs, such drugs even at suboptimal dosage may enhance their potency. To the best of our knowledge, this is the first time that the activities of these particular plant extracts have been shown to be enhanced with combination with ineffective concentrations of conventional antibiotic. Therefore, in the search for more potent antibacterial agents to treat wound and other bacterial infections, combination therapy could be an important strategy because the interactions could improve the efficacy, cure faster, provide broader spectrum than monotherapy, and prevent the emergence of resistance.

\section{CONCLUSION}

This study has shown that $C$. odarata leaf extracts could be effectively used in wound treatment as it inhibited the in vitro growth of $P$. aeruginosa isolated from infected wounds. $C$. odarata leaf extracts if properly harnessed could be a source of active antimicrobial agents for the development of drugs against the infections caused by $P$. aeruginosa. It could also help in the reduction of the emergence of antibiotic-resistant strains.

The combination of $C$. odarata extracts with conventional antibiotics improved the antimicrobial potency of the extracts. Further studies will be needed to establish the bioactive compounds in this plant, their mode of action against microbial isolates, and the mechanism of synergy as they are fundamental to the development of useful pharmacological agents.

\section{REFERENCES}

1. Amit KG, Priyam B, Purva M, Alphina K, Thanbuana BT, Shiny T, et al. Microbial epidemiology and antimicrobial susceptibility profile of wound infections in out-patients at a level 1 trauma centre. J Patient Saf Infect Control 2015;3:126-9.

2. Adhav R, Mantry P, Darwhekar GN. Wound healing medicinal plant of India: A Review. Int J Pharmacogn 2015;2:6-10.

3. Mohammed A, Adeshina GO, Ibrahim YK. Incidence and antibiotic susceptibility pattern of bacterial isolates from wound infections in a tertiary hospital in Nigeria. Trop J Pharm Res 2013;12:617-21.

4. Bello OM, Zack AM, Adikwu JG. The comparative studies of phytochemical screening of Piliostigma thonningii root and leaves 
extract. Asian J Plant Sci Res 2013;3:74-7.

5. Ammar I, Bardaa S, Mzid M, Sahnoun Z, Rebaii T, Attia H, et al. Antioxidant, antibacterial and in vivo dermal wound healing effects of Opuntia flower extracts. Int J Biol Macromol 2015;81:483-90.

6. Ezeigbo OR, Awomukwu DA, Ezeigbo IC. The antimicrobial and phytochemical analysis of the leaves of Aspilia africana on clinical isolates. Eur J Med Plants 2016;15:1-6.

7. Mbajiuka CS. Antimicrobial effects of the leaf extracts of Chromolaena odorata (Siam weeds) on some Human Pathogens. World J Pharm Res 2015;4:209-20.

8. Shiney MR, Revathi K. Wound healing activity of ethanolic extract of Chromolaena Odorata L. on excision wound model in rats. Glob J Res Anal 2015;4:31-4.

9. Usunobun U, Ewere GE. Phytochemical analysis, mineral composition and in vitro antioxidant activities of Chromolaena odorata leaves. J Pharm Sci 2016;2:16-20.

10. Odutayo F, Ezeamagu C, Kabiawu T, Aina D, Mensah-Agyei G. Phytochemical screening and antimicrobial activity of Chromolaena odorata leaf extract against selected microorganisms. J Adv Med Pharm Sci 2017;13:1-9.

11. Agaba TA, Fawole B. Phytochemical constituents of Siam weed (Chromolaena Odorata) and African custard apple (Annona Senegalensis). Int J Food Agric Vet Sci 2015;6:35-42.

12. Vijayaraghavan K, Ali SM, Maruthi R. Studies on phytochemical screening and antioxidant activity of Chromolaena odorata and Annona squamosal. Int J Innov Res Sci Eng Technol 2007;2:7315-21.

13. Vaisakh MN, Pandey A. The invasive weed with healing properties: A review on Chromolaena odorata. Int J Pharm Sci Res 2012;3:80-3.

14. Asomugha RN, Okafor PN, Ijeh II, Orisakwe OE, Asomugha AL, Ndefo JC. Toxicological evaluation of aqueous leaf extract of Chromolaena odorata in male wistar albino rats. J Appl Pharm Sci 2013;3:89-92.

15. Bhargava D, Mondal CK, Shivapuri JN, Mondal S, Kar S. Antioxidant properties of the leaves of Chromolaena odorata Linn. J Inst Med 2013;35:53-6.

16. Harlina H, Prajitno A, Suprayitno E, Nursyam H, Rosmiati. Potential study of kopasanda (Chromolaena odorata L.) leaves as antibacterial against Vibrio harveyi, disease causative agent of tiger shrimp (Penaeus monodon Fabricius) post larvae. J Aquac Res Dev 2015;6:1-5.

17. Itou RD, Ossibi AW, Pea C, Ntandou GF, Nokia CB, Obama JM, Abena AA. Anti inflammatory and analgesic effects of leaves of Chrolomolaena odorata L (King and Robinson). Afr J Pharm Pharmacol 2017;11:217-23.

18. Nwachukwu I, Aliga C, Upabi CF, Ukogo I. In vitro antibacterial effect of crude extract of Chromolaena odorata leaves on wound isolates. IOSR J Pharm Biol Sci 2016;11:49-52.
19. Nesakumar D, Sneha S, Monika M, Sivaseelan S. Synthesis and toxicology studies on Chromolaena Odorata (Communist green) extract. Trans Eng Sci 2016;4:82.

20. Hanphakphoom S, Thophon S, Waranusantigu P, Kangwanrangsan N, Krajangsang S. Antimicrobial activity of Chromolaena odorata extracts against bacterial human skin infections. Mod Appl Sci 2016;10:159-71.

21. Negi BS, Dave, BP. Evaluation of in vitro antimicrobial activity from the leaves extract of Cassia firstula Linn. J Pure Appl Microbiol 2010;4:557-64.

22. Kazhila CC. Plants and other natural products used in the management of oral infections and improvement of oral health. Acta Trop 2016;154:6-18.

23. Ulloa-Urizar G, Aguilar-Luis MA, De Lama-Odr' is MA, Camarena-Lizarzaburu J, Mendoza JV. Antibacterial activity of five Peruvian medicinal plants against Pseudomonas aeruginosa. Asian Pac J Trop Biomed 2015;5:928-31.

24. CLSI (Clinical and Laboratory Standard Institute). Performance Standards for Antimicrobial Susceptibility Testing; Seventeenth Informational Supplements. Wayne, Pennsylvania: Clinical and Laboratory Standards Institute; 2007. p. M100-S17.

25. Obi OJ, Ike AC. Prevalence and antibiogram profile of salmonellae in intensively reared and backyard chickens in Nsukka area, Nigeria. Nig J Biotechnol 2015;30:18-25.

26. Mbajiuka CS, Obeagu EI, Chude CN, Ihezie OE. Antimicrobial effects of Chromolaena odorata on some human pathogens. Int J Curr Microbiol Appl Sci 2014;3:1006-12.

27. Hridhya KV, Kulandhaivel M. Antimicrobial activity of Chromolaena odorata against selected pyogenic pathogens. Int J Pharmacogn Phytochem Res 2017;9:1001-7.

28. Oko JO, Audu JA, Ojeleye FS, Okey Q, Jakheng SP, Shittu KJ, et al. Comparative assessment of antibacterial activity of Chromolaena odorata leaf extracts against selected clinical bacterial isolates. J Adv Microbiol 2017;2:1-8.

29. de Oliveira SM, Falcao-Silva VS, Siqueira-Junior JP, Costa MJ, de Melo Diniz MF. Modulation of drug resistance in Staphylococcus aureus by extract of Mango (Mangifera indica) peel. Braz J Pharmacogn 2011;21:190-3.

\footnotetext{
How to cite this article:

Omeke PO, Obi JO, Orabueze NAI, Ike AC. Antibacterial activity of

leaf extract of Chromolaena odorata and the effect of its combination with some conventional antibiotics on Pseudomonas aeruginosa isolated from wounds. J App Biol Biotech. 2019;7(03):36-40. DOI: 10.7324/ JABB.2019.70307
} 